\title{
INICIJATIVA ZA AUTONOMIJU HERCEGOVINE S CILJEM SLABLJENJA RADIĆEVA UTJECAJA NA SKUPŠTINSKIM IZBORIMA 1925. GODINE
}

\author{
Ivica GLIBUŠIĆ \\ Filozofski fakultet \\ Matice hrvatske b.b. \\ $\mathrm{BiH}$ - 88000 Mostar \\ E-pošta: ivica.glibusic@sve-mo.ba
}

\author{
UDK 324(497.6)"1923/1925" \\ $329(497.6) " 1923 / 1925 "$ \\ Izvorni znanstveni rad \\ Primljeno: 26. travnja 2015 \\ Prihvaćeno: 11. lipnja 2015
}

\section{Sažetak}

Rezultati parlamentarnih izbora 1923. godine nagovijestili su oštru kampanju za sljedeće izbore u veljači 1925. Glavna stranačka sučeljavanja, kada je riječ o Hrvatima u $\mathrm{BiH}$, vodila su se između Hrvatske republikanske seljačke stranke (HRSS) i Hrvatske pučke stranke (HPS) s ciljem dobivanja legitimiteta predstavljanja Hrvata u političkom životu. Unatoč podršci franjevaca, na izborima 1925. godine, HPS je u Hercegovini doživio potpuni debakl ne dobivši niti jedan mandat. HRSS je vodio izbornu kampanju protiv svih: režimske vlasti, svojih disidenata, HPS-a i tako ostvario apsolutnu pobjedu među Hrvatima u $\mathrm{BiH}$. Na razini BiH HRSS je dobio 10 mandata (u Hercegovini 4, u Bosni 6), dok je Radićev disident Matej Kordić doživio potpuni izborni poraz u mostarskom okrugu, dobivši samo 103 glasa. Izborni rezultat omogućio je HRSS-u da s pravom u javnom i političkom životu može zastupati Hrvate u $\mathrm{BiH}$.

Ključne riječi: Hrvatska republikanska seljačka stranka (HRSS), Hrvatska pučka stranka (HPS), disidenti, autonomija, predizborna kampanja, stranački kandidati, izborne liste, stranačka promidžba, izbori, Mostarska oblast, izborni rezultat. 


\section{Uvod}

Izbori održani 18. ožujka 1923. ne mogu se okarakterizirati kao potpuno slobodni jer je vlada provodila represiju prema oporbenim političkim strankama. Pritisak prosrpskih vlasti nije naštetio HRSS-u, nego su represija i namještanje izbornih rezultata izazvali suprotan učinak - potpunu dominaciju te stranke u hrvatskom biračkom tijelu. HRSS je 1923. ostvario 70 zastupničkih mandata (na prethodnim izborima 50 mandata). ${ }^{1}$ $\mathrm{Na}$ spomenutim izborima u $\mathrm{BiH}$ izišlo je $77 \%$ birača, što se može smatrati visokim odzivom s obzirom na uvijete u kojima su izbori održani. ${ }^{2}$ Posebno je značajan uspjeh HRSS-a u BiH ako se promatra početak djelovanja te stranke na bosanskohercegovačkim prostorima. Iako se u dosadašnjoj literaturi navodilo da je prodor Radićeve ideje u $\mathrm{BiH}$ počeo tijekom 1922., to se medutim dogodilo sredinom 1919. ${ }^{3}$ U veoma kratkom vremenu HRSS se nametnuo kao najvažnija hrvatska stranaka u $\mathrm{BiH}$. Djelovanje HRSS-a bilo je otežano zbog djelovanja nekolicine disidenata koji su se u narodu predstavljali kao članovi HRSS-a, a ipak su djelovali samostalno. U mostarskom okrugu lista Radićeva disidenta Mateja Kordića osvojila je neočekivano veliki broj glasova i tako nanijela gubitak HRSS-u, što je u Zagrebu izazvalo veliko ogorčenje. Stjepan Radić je odlučio da se na sljedećim izborima u Hercegovini konačno raskrinka Kordića i druge disidente. Kada je riječ o HPS-u, koji je vodio kampanju uz pomoć hercegovačkih franjevaca, stanovništvo mu je odbilo dati podršku, tako da je ostao bez mandata. ${ }^{4}$ Rezultati parlamentarnih izbora 1923. godine nagovijestili su oštru kampanju za sljedeće izbore u veljači 1925. Disidenti HRSS-a, predvođeni Matejom Kordićem, nastojali su svoj dobar uspjeh na izborima 1923. kapitalizirati agresivnijom promidžbom na novim izborima. Glavna stranačka sučeljavanja, kada je riječ o Hrvatima u $\mathrm{BiH}$, vodila su se između HRSS-a i HPS-a, s ciljem dobivanja legitimiteta predstavljanja Hrvata u političkom životu.

\section{Ideja o autonomiji Hercego- vine i borba za muslimanske glasače}

Uoči novih izbora 1925. u Hercegovini se počela voditi kampanja koja se temeljila na izbornim rezultatima iz

1 Ferdo Čulinović, Dokumenti o Jugoslaviji. Historijat od osnutka zajedničke države do danas, Školska knjiga, Zagreb, 1968., str. 213, 241.

2 Isto.

3 Naime, nakon stvaranja nove države, hercegovački su franjevci provodili živu političku aktivnost. Župnici donje Bekije, predvodeni fra Silvestrom Vasiljem, fra Gabrijelom Grubisićem i fra Sebastijanom Lekom, 10. srpnja 1919. obavijestili su starješinstvo Hercegovačke franjevačke provincije u Mostaru da će se 31. srpnja 1919. sastati radi analiziranja svojih najvažnijih gospodarskih, političkih i drugih potreba. U pretresanju političkoga položaja najavili su da će se govoriti i o Seljačkoj pučkoj stranci te zbog toga traže da im starješinstvo Hercegovačke franjevačke provincije pravodobno dostavi svoje mišljenje. AHFPM, SP, sv. 52, 1919., f. 239.

4 Zlatko Matijević, "Hrvatska pučka stranaka i II. parlamentarni izbori u Kraljevini SHS (1923. god.)", u: Časopis za suvremenu povijest, Zagreb, 1996., br. 1-2, str. 40. 
1923. godine. Hercegovački narodni zastupnik Matej Kordić, kojega su podržavale radikalske novine, u Beogradu je 1. ožujka 1924. Ministarstvu unutarnjih poslova predložio osnivanje dviju ispostava mostarskoga seoskog kotarskog ureda - jednu na Širokom Brijegu, a drugu u Čitluku. Kordić je smatrao da će tim prijedlogom u narodu steći još veću popularnost: "U Hercegovini ima devet seoskih kotarskih ureda koje rijeka Neretva dijeli kroz sredinu okruga, tako da i ako je pola lijeve i desne obale: na istoku ima sedam kotarskih ureda, (gdje je većinsko srpsko pučanstvo), a na zapadu ima samo dva kotarska ureda: ljubuški i mostarski."5 Osim toga prijedloga, Kordić je od ministra unutarnjih poslova tražio i novi ustroj za autonomiju Hercegovine tako da se uspostave seoska vijeća kao općinska te kotarska, glavarska i okružna glavarska vijeća. Kordić također prosvjeduje jer ga se već dvije godine denuncira pred biračima i narodom. Odlučio se za podupiranje homogene radikalne vlade nakon što je demonstrativno istupao protiv Davidovićeva oporbenog bloka, a bez obzira na Radićev federalistički blok, nadajući se da će tako biti prihvaćen njegov prijedlog o autonomiji Hercegovine, koji je potpisao i Matiša Mlinarević Stipin, bivši član hercegovačkoga ogranka Hrvatske težačke stranke (HTS), Radićev disident. U prijedlogu stoji:

"Naročito nas Hercegovce veseli da je Hercegovina Ustavom određena kao cjelina, kao jedna oblasna nepodijeljena samouprava; te je to prvi korak za pokrajinsku autonomiju Hercegovine koju tražimo za slučaj davanja autonomija pokrajinama. Zahtijevajući prilikom toga promjene Ustava kako ne bi Hercegovina bila šesto okružje spahijske bosanske autonomije, već tražit ćemo u slučaju davanja autonomija da Hercegovina bude autonomna i samostalna ravnopravna bosanskoj autonomiji. Uz put izjavismo svoje stanovište koje zastupamo u pitanju odnošaja Hercegovine spram Bosne te Vas upozoravamo da ćemo javno u svojoj štampi zastupati ovo mišljenje: Hercegovina Hercegovcima, jer se nebrigom i neupravom jednaki pokazaše Sarajevo, Zagreb i Beograd s pravom Hercegovine i Hercegovaca."6

Osim navedenoga prijedloga Kordić je u duhu predizborne kampanje predlagao u svom glasilu Hercegovački slobodni dom izgradnju cesta po cijeloj Hercegovini, zatim izgradnju škola te povoljnije uvjete otkupa duhana. ${ }^{7}$ Kako Kordić nije imao političku snagu da dobije veća sredstva iz Beograda, njegova su obećanja ostala samo dio stranačke borbe za dobivanje naklonosti birača.

HRSS je za izbore koji su bili raspisani za 8. veljače 1925. glavnu predizbornu kampanju proveo prije proglašenja Obznane, koja je relativno spremno dočekana. Stjepan Radić je predvidio sve mogućnosti te je prije udara na stranku dao instrukcije stranačkim organizacijama o isticanju kandidacijskih lista na terenu. Neovisna radnička partija Jugoslavije (legalna

5 "Autonomija Hercegovine", u: Hercegovački slobodni dom, 6, Mostar, 1. kolovoza 1924., str. 2.

6 Isto, str. 2-3.

7 Isto. 
organizacija zabranjene KPJ) uoči izbora ponudila je koaliciju HRSS-u, što Radić i stranačko vodstvo nisu prihvatili jer su bili svjesni da bi time stranku doveli u još teži položaj. ${ }^{8}$ Previranje unutar HRSS-a uoči samih izbora dovelo je do stvaranja novih frakcija. Pokušalo se $s$ osnivanjem Neovisne hrvatske seljačke stranke $\mathrm{u}$ čije je privremeno vodstvo ušlo i nekoliko Hrvata iz BiH: Nikola Mihaljević, Mato Terman, Ivan Šimić, Ivan Veroni te Mate Golub. Preuzet je HRSS-ov program pod izgovorom da ga Radić ionako ne provodi. ${ }^{9} \mathrm{Ra}-$ dić, svjestan štete koju mu je Matej Kordić nanio u Mostarskoj oblasti na izborima 1923. godine, pokušao je spriječiti nove stranačke podjele.

Kada se $\mathrm{HZ}^{10}$ (Hrvatska zajednica) 25. studenoga 1924. proglasio republikanskim, Radić je na HRSS-ovu izbornu listu stavio i nekoliko njezinih članova, ali je predlagao da i ona postavi svoju listu za slučaj da sudovi spriječe postavljanje HRSS-ove liste, a da će svoje izbornike uputiti za koga treba glasovati. Taj je prijedlog prihvaćen pa je $\mathrm{HZ}$ postavio svoje liste $\mathrm{u}$ tri izborna okruga u kojima su predsjednici sudbenih stolova odbijali liste HRSS-a. Takav je postupak omogućio da Hrvati iziđu na izbore složnije nego na prethodne. Glavni je cilj bio osloboditi se beogradske tiranije. ${ }^{11}$

$\mathrm{Na}$ veljačkim parlamentarnim izborima 1925. godine koalicijskoj radikalno-samostalno-demokratskoj vladi najveći je protivnik bio Radić. Kako bi oslabila HRSS, vladajuća se garnitura služila svim sredstvima, posebice zastrašivanjem i raznim zabranama. ${ }^{12}$ Zabrinuti zbog stanja u zemlji, u siječnju 1925. u zastupničkom klubu JMO-a u Beogradu sastali su se Anton Korošec, Ljuba Davidović, Pavle Radić, Mehmed Spaho, Ivan Krstelj i Rudolf Bićanić. Nakon razmatranja postojećega stanja dana je zajednička izjava u kojoj je naglašeno da se zemlja nalazi u opsadnom stanju jer policijske vlasti uz pomoć povlaštenih "bandi" narušavaju slobodu okupljanja i dogovora, da se usprkos imunitetu uhićuju narodni zastupnici te da je zemlja dovedena u stanje nepoštovanja osnovnih ljudskih sloboda, sloboda na rad i govor. Tvrdi se da se primjena Zakona o zaštiti države ne primjenjuje samo na HRSS, kako bi se ta stranka lišila potpore ogromne većine Hrvata, nego i na druge stranke jer su već počela uhićenja i drugih stranačkih kandidata koji nisu po volji određenih političkih struktura. ${ }^{13}$

8 Hrvoje Matrović, Povijest Hrvatske seljačke stranke, Naklada P.I.P. Pavičić, Zagreb, 1999., str. 182.

9 Isto, str. 183.

10 Hrvatska zajednica živi pod tim imenom do 1925. Poslije toga i zajedno s disidentima HSS stvara Hrvatsku seljačku federalističku stranku. JeRe JaReB, Pola stoljeća hrvatske politike, Knjižnica Hrvatske revije, Buenos Aires, 1960., str. 25.

11 Rudolf Horvat, Hrvatska na mučilištu, Školska knjiga, Zagreb, 1992., str. 230.

12 Zlatko Matijević, "Hrvatska pučka stranka i Stjepan Radić (1919.-1928.)", u: Radovi Zavoda za hrvatsku povijest, 32-33, Zagreb, 1999.-2000., str. 262.

13 Atif Purivatra, Jugoslavenska muslimanska organizacija u političkom životu Kraljevine Srba, Hrvata i Slovenaca, Svjetlost, Sarajevo, 1977., str. 202. 
$\mathrm{U} \mathrm{BiH}$ je osim HRSS-a progonjen i JMO, ali i Zemljoradnička stranka, iako je okupljala isključivo pripadnike srpske nacionalnosti. ${ }^{14}$ Narodna radikalna stranka tumačila je da okupljanje muslimana oko Spahe i Hrvata oko Radića izravno ugrožava Srbe. Unatoč svim represivnim mjerama takvo je stajalište radikala izazvalo protureakciju druge strane pa je uslijedilo još čvršće povezivanje muslimanskih glasača oko JMO-a i hrvatskih oko HRSS-a. ${ }^{15}$ Radić i HRSS su i na tim izborima računali na pridobivanje muslimanskih glasača. U promidžbenim aktivnostima HRSS se koristio i vjerskim osjećajima muslimana predstavljajući letak Islam $i$ republika u kojem se, između ostaloga, pokušavalo ukazati na sličnost islamskoga učenja i HRSS-a. Tiskani su i drugi propagandni materijali $s$ porukom muslimanima da glasuju za HRSS. U takvoj predizbornoj kampanji HRSS je često isticao zastupljenost muslimana na svojim listama pa se tako u jednom letku navodi da su od 22 HRSS-ova zastupnička kandidata iz $\mathrm{BiH}$ osam muslimana Hrvata republikanaca. ${ }^{16} \mathrm{U}$ Slobodnom domu iznesen je podatak da se od 18 zastupnika JMO-a njih 17 izjašnjava $\mathrm{Hr}$ vatima te da se $90 \%$ muslimana u
BiH deklarira kao Hrvati i pristaje uz HRSS-ovu politiku. Muslimanski su glasači upozoreni da ih Spaho udaljava od HRSS-a te da bi to za njih moglo biti pogubno, jer bi podijeljeni glasovi mogli biti izgubljeni glasovi što nikome ne bi išlo u korist. ${ }^{17} \mathrm{Na}$ takve istupe HRSS-ova vodstva Spaho nije posebno reagirao. Uključivanje muslimana u HRSS-ovu izbornu kampanju u $\mathrm{BiH}$ donijelo je znatan uspjeh, što je omogućilo da se ne govori samo u ime Hrvata katolika nego i u ime muslimana.

HRSS je u Hercegovini imao svoga stalnog protivnika - HPS. Pokrajinsko vodstvo i HPS-ovi povjerenici za Hercegovinu krajem prosinca 1924. održali su u Mostaru sastanak i osudili Radića i njegov HRSS kao glavnoga krivca za neuspješno formiranje oporbene koalicije..$^{18}$ HPS je krenuo u svesrdnu promidžbenu kampanju kako bi izbjegao novi poraz na izborima. ${ }^{19}$ U kampanju se uključio i sam Anton Korošec, koji se nakon završetka dalmatinske turneje uputio u Hercegovinu. U Mostaru je 15. studenoga 1924. održao javnu skupštinu na kojoj je nazočilo nešto više od 1500 ljudi. Održani su i stranački sastanci u Širokom Brijegu, Grudama, Posušju, Vitini i Ljubuškom. Nakon održa-

14 Franko MirošEvić, "Prilozi za povijest zemljoradničkog (težačkog) pokreta u južnoj Dalmaciji od 1919. do 1925. godine", u: Historijski zbornik, 50, Zagreb, 1997., str. 124.

15 A. Purivatra, Jugoslavenska muslimanska organizacija u političkom životu Kraljevine Srba, Hrvata i Slovenaca, str. 189.

16 Isto, str. 194.

17 Isto, str. 195.

18 Zlatko Matijević, U sjeni dvaju orlova. Prilozi crkveno-nacionalnoj povijesti Hrvata u prvim desetljećima 20. stoljeća, Golden marketing - Tehnička knjiga, Zagreb, 2005., str. 201.

19 Z. Matıjević, "Pokušaj političkog reaktiviranja Hrvatske pučke stranke i veljački parlamentarni izbori (1923.-1925.)", u: Ćasopis za suvremenu povijest, br. 3, Zagreb, 1996., str. 340. 
nih sastanaka Korošec je zaključio da su seljaci nezadovoljni Radićevom politikom te da se ponovno priklanjaju HPS-u. ${ }^{20}$ Tako su Hrvati u Hercegovini nove izbore dočekali razjedinjeni između triju hrvatskih lista: HRSSove sa Stjepanom Radićem na čelu, HPS-ove sa zagrebačkim novinarom Stjepanom Barićem kao nositeljem liste i liste koju je sastavio Radićev disident Matej Kordić, bivši narodni zastupnik iz Drinovaca. ${ }^{21}$ Zbog stranačke razjedinjenosti, ali i zbog djelovanja nehrvatskih stranaka, dolazilo je i do incidenata. Jedan je takav izbio između Jelavićevih i Radićevih pristaša na blagdan svetoga Ivana, 27. prosinca 1924., u Sivcu, mjestu u ljubuškom kotaru. Shvaćajući što bi se moglo dogoditi, župnik je pozvao narod da se mirno raziđu kako se ne bi držali politički govori. Međutim, samostalni demokrat Ivo Jelavić ipak je držao govor, oštro napavši Radića i njegovu politiku te je pozvao narod da dobro otvori oči prije nego se odluči za koga će glasovati. Nakon obračuna između Jelavićevih i Radićevih pristaša, žandarmerija je stala na Jelavićevu stranu. U sukobima je poginuo radićevac Marko Miličević (Ilijin), a teško je ranjen Ivan Markotić. ${ }^{22}$

Budući da su se mjesec dana prije izbora intenzivirale stranačke aktivnosti, ministar unutarnjih poslova Božo Maksimović dao je županima upute o zaštiti javnoga reda i mira za vrijeme održavanja izbora. Iz krugova bliskih vladi pročula se vijest da glasačke kutije radićevaca i HZ-a ne će biti poništavane. Ta je odluka donesena nakon niza trzavica, a u detaljnim instrukcijama velikim županima o postupanju na dan izbora rečeno je da se HRSSove kutije trebaju otvoriti već u poslijepodnevnim satima. Županima su dane i upute za uhićenja predstavnika biračkih odbora i HZ-ovih i HRSSovih kandidata. ${ }^{23}$

$S$ ciljem sprječavanja HRSS-ove promidžbe vlasti su na različite načine onemogućavale okupljanje naroda. Tako je u vrijeme najavljenoga skupa HRSS-ovih simpatizera u Drinovcima, vlast istodobno u Ljubuškom organizirala polaganje vojne prisege. Ipak, HRSS-ov se skup održao, a podržali su ih i seljaci iz Gorice. ${ }^{24}$

Predizborna kampanja vođena je i u ostalim dijelovima $\mathrm{BiH}$ ali $s$ nešto manje žestine u usporedbi s Hercegovinom. Posebno se obraćala pozornost na djelovanje komunista čiji je rad bio zakonom zabranjen. Policijski organi imali su saznanja da će komunistički aktivisti podržati HRSS u znak podrške borbi protiv beogradskoga režima. Veliki župan Tuzlanske oblasti 19. ožujka 1924. uputio je dopis velikom županu Sarajevske oblasti upozorivši ga da je poglavaru tuzlanskoga kotara u ruke dopalo pismo komunista koji

20 Z. Matijević, U sjeni dvaju orlova, str. 209.

21 "Šarene izborne liste u Bosni i Hercegovini", u: Večernja pošta, 1057, Sarajevo, 14. siječnja 1925., str. 1.

22 Večernja pošta, 1184, Sarajevo, 1925. (Zbog oštećenja lista ne vidi se naslov i broj stranice.)

23 Večernja pošta, 1076, Sarajevo, 5. veljače 1925. (Zbog oštećenja lista ne vidi se naslov i broj stranice.)

24 Večernja pošta, 1240, Sarajevo, 24. kolovoza 1925. (Zbog oštećenja lista ne vidi se naslov i broj stranice.) 
svoje pristaše u $\mathrm{BiH}$ upućuju da na izbornim mjestima bez njihovih lista glasaju za HRSS-ovu listu. U slučaju da HRSS-ove liste budu suspendirane, komunisti pozivaju svoje članstvo da bojkotiraju izbore. ${ }^{25} \mathrm{U}$ spomenutom se pismu navodi: "Pošto u $\mathrm{BiH}$ neće nigdje biti naših lista, to smo zaključili da tamo svi naši drugovi glasaju za listu HRSS-a. U slučaju da u zadnji moment budu liste HRSS-a suspendirane tada da svi naši drugovi bojkotuju izbore."26 Državna sigurnost prijavila je Hrvatsku čitaonicu Alipašin most (Sarajevo) zbog kršenja zakonskoga rada. Navedeno je da se u Hrvatskoj čitaonici osnovalo protudržavno društvo radićevaca republikanaca. Kao poseban prijestup navodi se što se u spomenutoj čitaonici čitaju novine Slobodni dom, Hrvatski list, Hrvat. ${ }^{27}$ Odjel za državnu zaštitu pri Ministarstvu unutarnjih poslova Kraljevine SHS uputio je dopis velikom županu Sarajevske oblasti u kojem stoji da su se Radićeve pristaše sastale 30. prosinca 1924. u Spielfeldu (Austrija) gdje su razrađivali način kako izvesti državni udar s ciljem odcjepljenja državnoga teritorija i stvaranja posebne države koju bi činile Hrvatska i Bosna. U tu svrhu zaključeno je da se u pojedinim krajevima izvede oružana pobuna naroda $s$ ciljem izazivanja nestabilnosti državne vlasti. Iz Austrije će se Radićevi agenti i pristaše upućivati preko Maribora u Kraljevinu SHS. Naređeno je da se prate sve nove osobe na području Sarajevske oblasti. ${ }^{28}$

Stanje u zapadnoj Bosni počelo se komplicirati kada su u pitanju interesi HRSS-a. Naime, dio pristaša HRSS-a predvođenih Vinkom Lovrekovićem osnovali su Hrvatsku samostalnu seljačku stranku i unijeli još veću zbunjenost među hrvatske birače. Razlog osnivanja te stranke jest to što su smatrali da će ako uđu u koaliciju sa Srbima, postati dio vlasti. Oko Lovrekovića okupilo se i nekoliko Hrvata iz $\mathrm{BiH}$ - Nikola Mihaljević, Ivan Veron, Ivan Šimić i Dragan Golub. Ta je skupina u Banjoj Luci započela okupljanje protivnika Radićeva pravca, proširujući se i na druge krajeve Bosne, posebice Sarajevo. Među narodom se širila ideja da se prvi put $s$ uspjehom rješava hrvatskosrpski problem u BiH. ${ }^{29}$

Stanje na terenu postajalo je sve složenije kada su u pitanju ljudska prava i slobode. Kako se približavao dan izbora, povećavao se i teror. U mostarskom, ljubuškom, stolačkom, konjičkom i trebinjskom kotaru nastavljeno je sa zatvaranjem trgovina i radionica HRSS-ovih pristaša, a u Ljubuškom je uhićen i župnik fra Vid Čuljak. Veliki župan Mostarske oblasti smijenio je seoske poglavare i procjenitelje duhana te je postavio vlasti lojalne ljude. ${ }^{30}$

25 ABiH, VŽSO, POV., 1924., 172.

$26 \mathrm{ABiH}, \mathrm{VŽSO}$, POV., 1925., 691.

27 Isto.

$28 \mathrm{ABiH}, \mathrm{VŽSO}, \mathrm{POV} ., 1924 ., 172$.

29 Tomislav Išse, Djelatnost Hrvatske seljačke stranke u BiH do zavođenja diktature, Svjetlost, Sarajevo, 1981., str. 221.

30 "Kandidati HPS-a u Hercegovini", u: Narodna sloboda, 2, Mostar, 1925., str. 1-2. 
Uoči izbora u Hercegovini formirano je i prijavljeno sedam kandidacijskih lista: lista samostalnih demokrata i radikala, čiji je nositelj dr. Laza Marković; JMO-va lista - nositelj Salih Baljić, bivši narodni izaslanik iz Mostara; HRSS-ova lista sa Stjepanom Radićem na čelu; lista Srpske stranke (velikosrbi) s nositeljem Radovanom Petrovićem; lista Davidovićevih demokrata i zemljoradnika koju je predvodio Vasilj Grgić, ravnatelj sarajevske "Prosvjete"; HPS-ova lista s nositeljem Stjepanom Barićem, novinarom iz Zagreba, te lista Radićevih disidenata s Matejom Kordićem na čelu. ${ }^{31}$

HPS je upozoravao da bi bilo pogubno da se birači ne odazovu glasovanju ako ne bude HRSS-ove liste te da bi se stranačko vodstvo, smatraju u HPS-u, $\mathrm{u}$ tom presudnom trenutku moralo izdignuti iznad stranačkih interesa i javno reći da svi Hrvati moraju podržati hrvatske stranke: "Ako, dakle, ne bude HRSS-ove kutije, dužnost je svih Hrvata da glasuju za jednu od opozicionalnih hrvatskih stranaka. U Hercegovini, a i u nekim okruzima u Bosni, jedina opozicionalna hrvatska stranka je HPS. Hrvati ne smiju glasovati za nehrvatske stranke." ${ }^{32}$ HPS je, između ostaloga, upozoravao da državne službe, stranke ili pojedinci ne smiju vršiti pritisak zastrašivanjem ili sprječavanjem da bilo tko glasuje prema vlastitoj želji. Od glasača je zatraženo da takve slučajeve prijave stranačkoj središnjici. Mostarska oblast bira sedam zastupnika, a nositelj HR-
SS-ove liste je Stjepan Radić. Stavljanjem Radića za nositelja liste u Hercegovini, jasno se poručilo glasačima da Matej Kordić nema nikakve veze s HRSS-om. Hercegovina je tada imala 265.330 stanovnika od ćega 113.933 katolika, 61.242 muslimana i 89.441 pravoslavaca. HRSS je preko svoga glasila Dom propagirao da će većina muslimana glasovati za njih. ${ }^{33}$ Unatoč mnogim pritiscima i kampanji koja je vođena protiv stranke, HRSS je ipak spremno dočekao izbore u Hercegovini. Priželjkujući HRSS-ov neizlazak na izbore, HPS je pozvao hrvatske glasače da glasuju za hrvatske stranke. Poziv je upućen i HRSS-ovcima. Također HPS je poručio da je u svakom slučaju trebalo odbaciti listu Mateja Kordića zbog njegove suradnje $s$ beogradskim režimom.

Nakon što se pojavila mogućnost da na izborima ne bude HRSS-ove izborne kutije, HPS je počeo jaku promidžbu za koga onda glasovati, pozivajući pristaše Radićeve stranke da glasuju za HPS. Dakle, ako bi Hrvati radićevci u Hercegovini bili spriječeni u glasovanju i ostali kod kuće na dan izbora, od svoja četiri mandata Hrvati bi dali tri radikalima, a jedan demokratima, što znači da bi sva četiri imali Srbi. HPS poziva sve $\mathrm{Hr}$ vate da na dan izbora iziđu i glasuju. Radićevcima je upućena poruka da, ako im tadašnji režim spriječi kandidiranje stranke na izborima, svakako glasuju za HPS koji će na pravi način zastupati interese Hrvata. ${ }^{34}$ Koriste-

31 "Izborna lista u Bosni i Hercegovini", u: Narodna sloboda, 2, Mostar, 1925., str. 3.

32 "Hercegovački Hrvati otvorite oči!", u: Narodna sloboda, 3, Mostar, 1925., str. 1.

33 "Kandidatske liste", u: Slobodni dom, 1, Mostar, 1925., str. 9.

34 "Hoćemo li glasati", u: Narodna sloboda, 4, Mostar, 29. siječnja 1925., str. 1. 
ći novonastalu situaciju, skupština Radikalne stranke održana je u Ljubuškom 26. siječnja 1925. uz mobilizaciju cjelokupne oružane sile. $\mathrm{Na}$ skupśtini su govorili Laza Marković i Ivo Jelavić. ${ }^{35}$

Unatoč takvim okolnostima 15. prosinca 1924. Predsjedništvo HRSS-a zaključilo je kandidacijske liste. ${ }^{36} \mathrm{No}-$ sitelji lista bili su: za Mostarsku oblast Stjepan Radić, Tuzlansku Juraj Krnjević, Sarajevsku Pavle Radić, Travničku Ivo Celan, Banjolučku Pavle Radić, Bihaćku Ibrahim Pajazetović. ${ }^{37}$

\section{Izborni rezultati po oblastima}

Rezultati izbora od 8. veljače 1925. iznenadili su vladajuće krugove u Beogradu jer su očekivali da će nakon provedenih represija HRSS ostvariti znatno slabiji rezultat. Unatoč nepovoljnim uvjetima HRSS je dobio 532.872 glasa, odnosno 60 tisuća glasova više nego na izborima $1923 .{ }^{38}$ Zbog D'Hondtova sustava proračuna mandata, koji daje prednost onima koji su dobili više glasova, HRSS je izgubio nekoliko mandata te je u novoj skupštini dobio 67 zastupničkih mjesta. HRSS-ov uspjeh temeljio se na masovnom okupljanju Hrvata, i iz Hrvatske i iz $\mathrm{BiH}$, oko politike Stjepana Radića $s$ ciljem rješavanja hrvatskoga pitanja te gospodarskih, socijalnih i drugih problema u državi. Osim seljaštva, Radiću se u Hrvatskoj priklonilo i građanstvo. No, vodstvo stranke ni nakon izbora nije pušteno iz zatvora, a pritisak Pašićeve vlade nastavljen je odugovlačenjem ovjere mandata HRSS-ovim zastupnicima. ${ }^{39}$

Prema dokumentu koji je 9. veljače 1925. izdalo Ministarstvo unutarnjih poslova, u Narodnu skupštinu ulazi Radikalna stranka sa 140 mandata, Samostalna demokratska stranka $s$ 22 mandata, HRSS sa 67 mandata, Davidovićevi demokrati s 37 mandata, Koroščeva Slovenska ljudska stranka s 20 mandata, Jugoslavenska muslimanska organizacija s 15 mandata, Njemačka stranka s pet mandata, zemljoradnici s četiri, Crnogorski federalisti s tri mandata te Džemijet i Slovenski kmetijci s po jednim mandatnim mjestom. ${ }^{40}$ Rezultati veljačkih izbora pokazali su da se odnos između režimskih i oporbenih stranaka nije značajnije izmijenio. HRSS je postigao velik uspjeh pokazavši time svoju snagu na političkoj sceni Kraljevine SHS. ${ }^{41}$

$\mathrm{U} \mathrm{BiH}$ su radikali dobili 21 mandat, JMO 15, HRSS 10, a zemljoradnici dva mandata. Na temelju broja glasova koje su osvojile pojedine stranke,

35 "Domaće vijesti i naši dopisi", u: Narodna sloboda, 4, Mostar, 29. siječnja 1925., str. 3.

36 T. IšEK, Djelatnost Hrvatske seljačke stranke u BiH do zavođenja diktature, str. 222.

37 "Kandidatske liste", u: Slobodni dom, 1, Mostar, 1925., str. 10.

38 Bosiljka Janjatović, "Karađorđevska centralizacija i položaj Hrvatske u Kraljevstvu (Kraljevini) SHS", u: Casopis za suvremenu povijest, br. 1, Institut za suvremenu povijest, Zagreb, 1995., str. 69.

39 H. Matкović, Povijest Hrvatske seljačke stranke, str. 185.

40 R. Horvat, Hrvatska na mučilištu, str. 230.

41 Tonč Šritin, "Prodor i pobjeda HSS-a u Dalmaciji (1923.-1928.)", u: Radovi Zavoda za hrvatsku povijest, 32-33, Zagreb, 1999.-2000., str. 312. 
vidljivo je da je u Mostarskoj oblasti dio muslimanskoga pučanstva glasovao za HRSS i za radikale. Također, treba reći da je dio hrvatskoga pučanstva, koji je bio u sprezi s vlastima, tj. radio u državnim institucijama, glasovao za radikale plašeći se gubitka radnoga mjesta. Unatoč HRSS-ovoj izbornoj pobjedi Beograd ga je krivio za događaje koji su se, prema vladinim izvorima, događali u Hercegovini.

Rezultati izbora u mostarskom okrugu objavljeni su i u posebnom izdanju Večernje pošte. Prema tim podatcima radikali su dobili 17.180 glasova, Spaho 10.868, HRSS 24.349, Srpska stranka 230, Vasilj Grgijić 487, Pučka stranka 439 i Kordić 103 glasa što znači da su radikali dobili dva mandata, Spaho jedan i HRSS četiri mandata. ${ }^{42}$ Od 48 zastupnika izabrano je 10 HRSS-ovih zastupnika (u Hercegovini 4, u Bosni 6), 15 zastupnika JMO-a, 21 radikal i dva zemljoradnika. Budući da je JMO bio bliži HRSS-u nego radikalima, u $\mathrm{BiH}$ je oporba dobila 25 mandata prema 23 mandata radikala i zemljoradnika. U Hercegovini je HRSS dobio četiri mandata: Stjepana Radića, Tomu Kovačevića, seljaka iz Banske Hrvatske, Nikolu Preccu, predsjednika područne organizacije HRSS-a za Hercegovinu i Ivana Radića, seljaka iz Drinovaca. ${ }^{43} \mathrm{U}$ sarajevskom je okrugu JMO dobio 26.630 glasova, Radikalna stranka 24.302, HRSS 8437, zemljoradnici 1776, a 409 za ostale. Za HRSS izabran je Pavle Radić. U bihaćkom okrugu hrvatske stranke nisu dobile mandat. U banjolučkom okrugu radikali su dobili 45.640 glasova, JMO 14.819, HRSS 12.929, zemljoradnici 6400 , radikalski disidenti 1940, muslimanski egzekutivci 1072, Velikosrpska stranka 480, Hrvatska pučka stranka 301, a lista Vinka Lovrekovića 289 glasova. HRSS je dobio jedan mandat. U travničkom je okrugu HRSS dobio 18.000 glasova, JMO 15.000, radikalna stranka 14.000, Samostalna demokratska stranka 112, zemljoradnici 875. Izabrana su 3 člana HRSS, 2 muslimana i 2 radikala. U tuzlanskom je okrugu JMO dobio oko 37.000 glasova, Radikalna stranka oko 35.000, HRSS 8000. Izabrano je pet muslimana, pet radikala i jedan član HRSS-a. ${ }^{44}$

\section{Izmišljena pobuna u Hercegovini}

Ministarstvo unutarnjih poslova je 10. veljače 1925. izdalo priopćenje u kojem se tvrdi da su, nakon pobjede oporbenoga bloka u Hercegovini, radićevci u mnogim mjestima pokušali rušiti kuće, naročito srpske. Pojedinci su se osobno obraćali ministru unutarnjih poslova moleći za pomoć jer su se bojali da žandarmerija ne će biti dovoljno učinkovita u njihovoj obrani. Mnogobrojni brzojavi upozoravali su da je stanje nakon objave izbornih rezultata i pobjede oporbenoga bloka za tamošnje srpsko pučanstvo postalo slično onom nakon

42 "Prvi rezultati izbora", u: Večernja pošta, posebno izdanje, Sarajevo, 9. veljače 1925., str. 1.

43 "Izborni rezultati", u: Narodna sloboda, 6, Mostar, 13. veljače 1925., str. 1.

44 R. Horvat, Hrvatska na mučilištu, str. 232-234. 
sarajevskoga atentata 1914. godine. ${ }^{45}$ Bivši ministar Šefkija Behmen je 12. veljače 1925. u Beogradu novinarima komentirao izbore u $\mathrm{BiH}$ i izjavio da su izbori prošli pod velikim pritiskom. Narod je tri mjeseca bio izložen raznim torturama koje se ne mogu ni zamisliti u jednoj pravnoj državi. Behmen ističe da nakon godinu dana raznih prijetnji, presija i proganjanja muslimanskoga i katoličkoga pučanstva slijede izborne metode takozvane Pašić-Pribićevićeve vlade, kojima je okrunjena sva nepravilnost i nepravda u $\mathrm{BiH}$ : "Građanima nije bila zajamčena osobna ni imovinska sigurnost, a napadi su bili svakodnevni. Narod je bio izvrgnut teroru četnika koji su naoružani puškama krstarili naseljima. (...) Oni su obilazili sela i govorili narodu kako su izbori za muslimane i katolike u petak, pa ne trebaju u nedjelju 8. veljače ići na glasovanje jer bi se izložili opasnosti da dođu u sukob s radikalima."46 U nekim mjestima seljaci se nisu dali preplašiti pa su radikali pribjegli drugim metodama. U konjičkoj općini u selima Obri i Čelebići s birališta su otjerani čuvari kutija, a u njihovoj odsutnosti oporbene su kuglice pribrojene radikalima, a na nekim je biralištima glasovalo više osoba nego ih je bilo upisano u popise birača. ${ }^{47}$

Iz Mostara je 12. veljače 1925. hrvatskim novinama poslano sljedeće izvješće o stanju nakon izbora:
"Vjerujući u pobjedu opozicije, narod je poslije izbora počeo u znak radosti paliti krjesove, a na crkvama su zvonila zvona. Pristaše vladinih stranaka pokušali su na nekim mjestima oprijeti se spomenutim hrvatskim manifestacijama. Radi toga je dolazilo do okršaja, te je alarmirana i žandarmerija iz Vrgorca. Oružnici su u mnogim mjestima uhitili uglednije ljude. Tako je u kotaru ljubuškom uhićeno oko 200 hrvatskih seljaka, premda je već 11 . veljače bio svuda uspostavljen mir." 48

Međutim, kada su nakon završenih izbora HRSS-ovci htjeli proslaviti pobjedu, u mnogim mjestima $\mathrm{Hr}$ vatske i $\mathrm{BiH}$ intervenirale su vlasti, a i vojska. ${ }^{49}$ Narodna sloboda je nakon izbora objavila tekst pod naslovom Lažne vijesti o pobuni u Hercegovini. Prema izvješću provladinih listova, u mostarskom, ljubuškom i djelomično stolačkom kotaru oporbenjaci su terorizirali vladine pristaše, činili ubojstva, palili im kuće i uništavali njihova imanja. Prema tim vijestima, u navedenim kotarima više nije bilo vladinih pristaša. No, kasnije se ispostavilo da te vijesti nisu točne te da se radi o dezinformiranju javnosti jer paljenja kuća i proganjanja pristaša radikalne ili bilo koje druge stranke nije bilo. Priče da radićevci u Hercegovini progone radikale, odnosno Srbe, uredništvo Narodne slobode kasnije opovrgava, ali u broju od 11. veljače javlja da je u Ljubuški došla vojska kako bi uredovala protiv bun-

45 Isto, str. 236.

46 Isto, str. 238.

47 Isto, str. 239.

48 Isto, str. 240.

49 B. Janjatović, Politički teror u Hrvatskoj, 1918.-1935., Hrvatski institut za povijest, Zagreb, 2002., str. 82. 
tovnika te da se iz povjerljivih izvora doznaje da je zapovjednik izjavio da "nema protiv koga uredovati jer je narod miran". ${ }^{50}$ Narodna sloboda javlja i da su nakon intervencija iz Sarajeva i Beograda u Čapljini i Ljubuškom uslijedila uhićenja Hrvata katolika i muslimana jer su navodno sudjelovali u paljenju krjesova nakon izbora. Ekstremni radikali su u Hercegovini provodili razne oblike nasilja ne bi li zastrašili narod te tako dobili što više glasova. Izazvali su teške pa i krvave sukobe, a na dan izbora na pojedinim je biralištima uredovala vojska i žandarmerija. ${ }^{51}$

Narodna sloboda objavljivala je pritužbe naroda koje su stizale sa svih strana Hercegovine koje su govorile o nepravilnostima na izborima. $\mathrm{Na}$ ime, narod se žalio da mnogih nema na izbornim popisima za što su bile krive i seoske starješine koje se nisu potrudile da svi birači iz njihovih sela budu na vrijeme registrirani. Seoski glavari mostarskoga kotara žalili su se da njihove reklamacije nisu prihvaćene, što potvrđuje i podatak da su u Čitluku pred glasačkom kutijom odbijena 53 birača. Takvih je slučajeva bilo na više seoskih birališta pa i u samome Mostaru. Prema novinskim napisima, izborni je dan protekao mirno. Bolesni i nepokretni birači fijakerima su bili dovezeni na mjesto glasovanja. Također, Narodna sloboda pisala je da je vlada izdala priopćenje u kojem se žali na oporbu da je u nekim prečanskim krajevima došlo do nemira i demonstracija hrvatskoga i muslimanskoga pučanstva, a spominje se Mostar i Hercegovina. Međutim, u Mostaru nije bilo ni nereda ni demonstracija. ${ }^{52}$ Također, 17. veljače 1925. Narodna sloboda objavila je izvješće iz Čapljine o progonima i zatvaranju Hrvata katolika i muslimana. Vidjevši da su radikali dobili većinu na državnoj razini, starješina kotarske ispostave u Čapljini, Pašalić naredio je uhićenje svih onih za koje je smatrao da su protivnici vlasti. U to se upustilo i čapljinsko Radikalsko vijeće na čelu s Danilom Pudarom, a pomagali su mu špijuni Pero Delić i Neđa Sarić. Tako je Pašalić zbog proslave izbornih rezultata Šimuna Kapetanovića kaznio $s$ mjesec dana zatvora, po 15 dana zatvora kažnjeni su Salem Metifović i Meho Fazlagić, 10 dana zatvora dobili su Pero Dujmović, Mirko Vego i Jure Vukšić iz Trebižata, a nekoliko je ljudi kažnjeno $s$ petodnevnom zatvorskom kaznom. U mjestu Blizanci također su progonili sve one koji su bili protiv radikala pa je pritvoreno 14 stanovnika toga mjesta. ${ }^{53}$ Žandari su u Ljubuškom prekoračili ovlasti i tukli seljake, piše Narodna sloboda, pri čemu je teško ozlijeđen Ivan Miličević, glavar iz Lipna. U noći 8. prosinca 1925. u selu Lipno došlo je do sukoba između mladih toga sela i susjednih Radišića. Nakon što je jedan mladić iz Radišića ranjen iz puške, ljubuški su žandari 10. prosinca 1925. došli u Lipno, uhitili 11 mladića i odveli ih u žandar-

50 "Lažne vijesti o pobuni u Hercegovini", u: Narodna sloboda, 8, Mostar, 1925., str. 1.

51 Isto.

52 "Domaće vijesti", u: Narodna sloboda, 6, Mostar, 13. veljače 1925., str. 3.

53 "Naši dopisi", u: Narodna sloboda, 7, Mostar, 20. veljače 1925., str. 2-3. 
merijsku postaju u Ljubuški, gdje su pretučeni i zlostavljani bili prisiljeni priznati krivnju. ${ }^{54}$

Unatoč dobrim izbornim rezultatima, Hrvati i dalje nisu imali pristupa državnim službama. Narodni zastupnik Kostić 17. lipnja 1925. piše da su se na to žalili seljaci iz cijele $\mathrm{BiH}$ : "Hrvati nemaju nikakva pristupa u službe, dok prije ne pljunu na svoje hrvatstvo. Naše hrvatske činovnike bacaju u zabitije krajeve, ili ih naprosto ostavljaju na cjedilu, a kod nas u Bosni su gotovo sve sami Srbi na upravi. Ako dođemo na poštu, na željeznicu, u kotar, na županiju, svuda su sve sami Srbi ili oni ljudi koji su zaboravili na hrvatstvo." ${ }^{\text {}}$

HRSS je u Hercegovini i Bosni dobio naklonost birača jer je radio na poboljšanju životnih uvjeta. Radio je također na opismenjavanju pučanstva i razvoju školstva što je doprinijelo boljem statusu državnih službenika hrvatske nacionalnosti. $\mathrm{Na}$ području Hercegovine bila je prisutna glad što je ionako teške životne uvjete još više pogoršalo. Radić je sa svojim stranačkim vodstvom iz Zagreba i predstavnicima na terenu radio na dostavljanju pomoći za izgladnjelo stanovništvo. Zalaganje HRSS-a za Hrvate u $\mathrm{BiH}$ rezultiralo je velikom potporom na ovim i sljedećim izborima. HPS unatoč podršci dijela svećenstva Katoličke crkve nije ostvario pozitivan rezultat, okrivivši HRSS da se u predizbornoj kampanji koristio nedopuštenim sredstvima $\mathrm{i}$ lažnim obećanjima. Druge političke stranke i neovisne kandidacijske liste ostvarile su zanemariv uspjeh na ovim izborima.

54 "Pašić-Radićevi batinaši na djelu", u: Narodna sloboda, 50, Mostar, 18. prosinca 1925. str. 1.

55 Dom, 8, Zagreb, 24. lipnja 1925., str. 3; "Koliko je i kako je napredovao hercegovački seljak", u: Dom, 15, Zagreb, 12. kolovoza 1925., str. 3-4. 


\section{An initiative for the autonomy Herzegovina with the aim of weakening Radic's influence on the 1925 parliamentary elections}

\section{Summary}

The results of the 1923 parliamentary elections announced a fierce campaign for the next elections in February 1925. Dissidents of HRSS led by Matej Kordic tried to capitalize their good results in the 1923 elections through the aggressive promotion of new elections. They were supported by the Serbian Radicals, and to attract voters in Herzegovina, they focused on the idea of the autonomy of Herzegovina in their campaign.

Major political confrontations, when it comes to Croats in Bosnia and Herzegovina, occurred between HRSS and HPS, both of them aiming to obtain legitimacy for representing Croats in political life.

Despite the support of the Franciscans at the 1925 elections, HPS in Herzegovina suffered a complete debacle, gaining not a single seat. On the other hand, HRSS led a campaign against all - the regime's authority, its dissidents and HPS, achieving thus absolute victory among Croats in Bosnia and Herzegovina. In the Kingdom of Serbs, Croats and Slovenes, HRSS won 67 seats, whereas in Bosnia and Herzegovina, they won 10 seats (4 in Herzegovina, 6 in Bosnia). Radic's dissident Matej Kordic suffered a heavy defeat in the electoral district of Mostar, winning only 103 votes. Belgrade authorities, dissatisfied with the electoral victory of HRSS, announced that after the proclamation of election results an armed rebellion occurred in Herzegovina followed by the persecution of non-Croat population. Due to such allegations, additional police and military forces were sent to Herzegovina, which after some time denied there had been any rebellion. The election results gave HRSS the right to represent Croats in Bosnia and Herzegovina in public and political life.

Keywords: HRSS (Croatian Republican Peasant Party), HPS (Croatian Folk Party), dissidents, autonomy, election campaign, political candidates, election lists, political party promotion, elections, Mostar district, election results. 